\title{
Incorporating electrostatic effects into the effective stress relation - Insights from chalk experiments
}

\author{
Nermoen, Anders; Korsnes, Reidar Inge; Storm, Eirik Vika; Stodle, Trond; Madland, Merete Vadla; \\ Fabricius, Ida Lykke
}

\section{Published in:}

Geophysics

Link to article, DOI:

10.1190/GEO2016-0607.1

Publication date:

2018

Document Version

Publisher's PDF, also known as Version of record

Link back to DTU Orbit

Citation $(A P A)$ :

Nermoen, A., Korsnes, R. I., Storm, E. V., Stodle, T., Madland, M. V., \& Fabricius, I. L. (2018). Incorporating electrostatic effects into the effective stress relation - Insights from chalk experiments. Geophysics, 83(3), MR123-MR135. https://doi.org/10.1190/GEO2016-0607.1

\section{General rights}

Copyright and moral rights for the publications made accessible in the public portal are retained by the authors and/or other copyright owners and it is a condition of accessing publications that users recognise and abide by the legal requirements associated with these rights.

- Users may download and print one copy of any publication from the public portal for the purpose of private study or research.

- You may not further distribute the material or use it for any profit-making activity or commercial gain

- You may freely distribute the URL identifying the publication in the public portal 


\title{
Incorporating electrostatic effects into the effective stress relation - Insights from chalk experiments
}

\author{
Anders Nermoen ${ }^{1}$, Reidar Inge Korsnes ${ }^{2}$, Eirik Vika Storm², Trond Stødle ${ }^{2}$, \\ Merete Vadla Madland ${ }^{1}$, and Ida Lykke Fabricius ${ }^{3}$
}

\begin{abstract}
Which forces are responsible for holding highly porous chalks together? We use the effective stress to quantify the electrostatic effects around particle contacts originating from the adsorption of ions onto charged mineral surfaces. The induration of chalk indicates that it is held together by contact cement, where planar crystal contacts allow the action of short-ranged adhesive Van der Waals forces. At particle distances exceeding a few nanometers, recent studies have indicated electrostatic repulsion between waterembedded adjacent particles. The magnitude of the repelling force depends, among other parameters, upon temperature and brine composition. Our premise is that by perturbing the electrostatic forces at the particle level, we can control the mechanical behavior of chalk samples tested in triaxial cells. We report the results of an
\end{abstract}

experimental series, investigating how the mechanical strength and stiffness varied among samples saturated with four different brines, tested at two temperatures, and tested directly or after aging for three weeks at high temperature. We associate stiffness with bulk modulus and strength with the stress at yield. Systematic softening and weakening is observed, especially when the pore fluid is sulfate bearing, as well as for some high-temperature experiments and for aged samples. However, softening and weakening are not totally correlated, and neither brine composition, temperature, nor aging can alone dictate the mechanical behavior of the chalk - a combination is required to predict the chalk stiffness and strength. To obtain a coherent description of our experimental results, we estimated the electrostatic stress arising from ion adsorption and found it unnecessary for these experiments to postulate significant dissolution or precipitation-related changes to the rock frame.

\section{INTRODUCTION}

The mechanical behavior of chalks has generated interest in the industrial community since the North Sea, Ekofisk field subsidence was discovered. To remedy the compaction problem, the previously depleted pore pressure was increased by injection of seawater. The seawater injection led to increased recovery rates, but unexpectedly the compaction prevailed even where the pore pressure, and thereby the effective stress, approached the level before oil production started (Hermansen et al., 2000; Nagel, 2001; Doornhof et al., 2006). The prevailing compaction in the water-flooded zones at preproduction stress conditions indicated that not only the load and pore pressure, but also the pore-fluid composition, dictate the mechanical behavior of chalk (Newman, 1983; Sylte et al., 1999; Hellmann et al., 2002; Korsnes et al., 2008). As such, a water-weakening effect was proposed.

Significant efforts have been put into understanding how, and to what extent, alterations to the water chemistry changes the mechanical behavior of chalk. Several aspects of chalk strength have been studied. It has been found that the pore-fluid composition affects the (1) tensile strength from Brazilian tests (Madland et al., 2002; Risnes et al., 2003; Heggheim et al., 2005), (2) shear strength (i.e., the frictional coefficient and cohesion) (Madland et al., 2002; Risnes et al., 2005), (3) the position of the failure envelope

Manuscript received by the Editor 22 November 2016; revised manuscript received 16 November 2017; published ahead of production 22 January 2018 ; published online 16 March 2018.

${ }^{1}$ University of Stavanger, The National IOR Centre of Norway; IRIS AS, International Research Institute of Stavanger, Stavanger, Norway. E-mail: anders. nermoen@iris.no; merete.v.madland@uis.no.

${ }^{2}$ University of Stavanger, The National IOR Centre of Norway, Stavanger, Norway. E-mail: reidar.i.korsnes@uis.no; eirik.storm@archerwell.com; trond. stodle@gmail.com.

${ }^{3}$ University of Stavanger, The National IOR Centre of Norway, Stavanger, Norway; Technical University of Denmark, Kongens Lyngby, Denmark. E-mail: ilfa@byg.dtu.dk.

(C) 2018 Society of Exploration Geophysicists. All rights reserved. 
(Madland et al., 2002; Risnes et al., 2005), and (4) the time-dependent creep deformation at constant stress and pressure condition. At high temperatures, sulfate and magnesium ions are particularly important to trigger accelerated creep strain rates during continuous flow-through and compaction, although the way that these two ions dictate overall compaction rates differ (e.g., Nermoen et al., 2014, 2015). Experiments indicate that the ion exchange on available surface sites as well as the dissolution of calcite and formation of secondary minerals can play a role in dictating the observed mechanical response (Madland et al., 2011); (5) Within the elastic domain, water softening of chalk at elevated temperatures has been observed, in triaxial cell experiments (e.g., Madland et al., 2011; Megawati et al., 2013, 2015) and in elastic moduli derived from ultrasonic velocities (Japsen et al., 2004; Katika et al., 2015).

a)

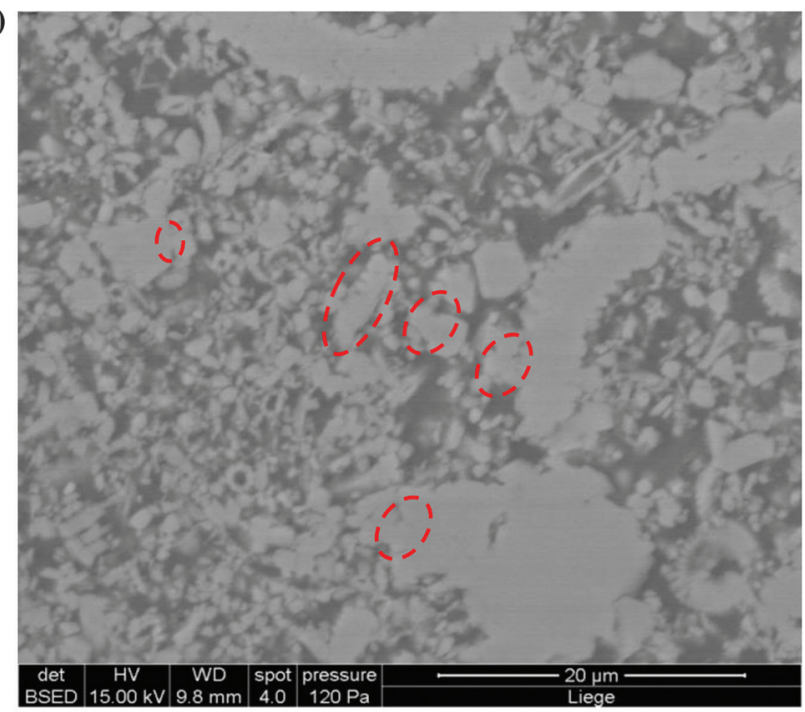

b)

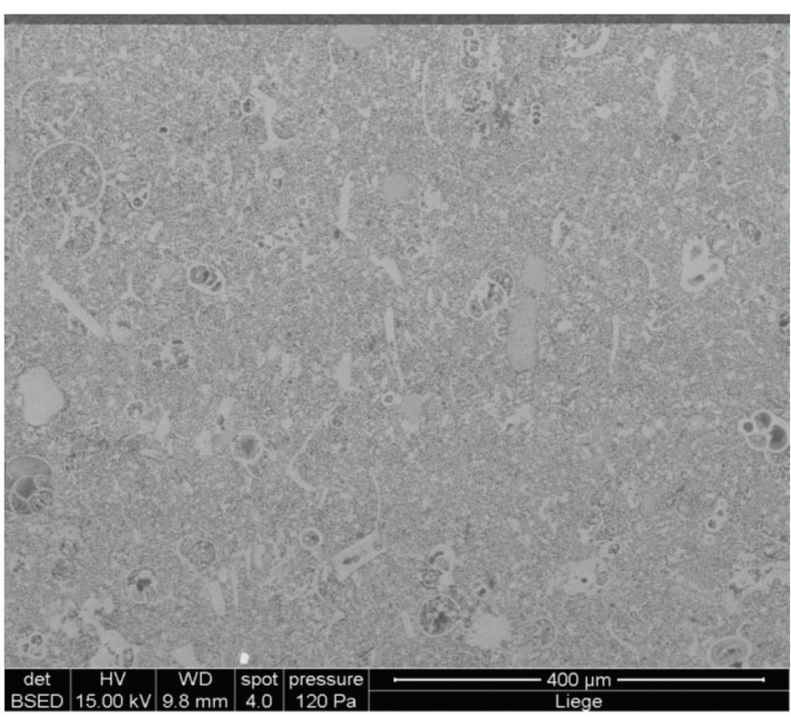

Figure 1. Backscatter electron micrographs of polished thin section of Liegè chalk used in this study. (a) A high magnification, where contact cementations are likely to be seen (dashed ellipses). (b) A lower magnification to illustrate depositional texture (silt- and microfossil-bearing calcareous mudstone).
The mechanical elasticity and strength of porous rocks can be quantified from rock mechanical testing. At hydrostatic conditions, which are the focus of this paper, the observed elastic bulk modulus $K_{\text {drained }}$ of the rock can be obtained from incremental variations in effective stress $\sigma_{\text {hyd }}^{\prime}$, and the corresponding variation in volumetric strain $\varepsilon_{\mathrm{vol}}$ :

$$
\sigma_{\text {hyd }}^{\prime}=K_{\text {drained }} \varepsilon_{\mathrm{vol}}
$$

It should be noted that $K_{\text {drained }}$ derived from mechanical triaxial loading tests typically include contributions from elastic as well as plastic deformation such that it tends to be smaller than the purely elastic modulus of the frame $K_{\text {bulk }}^{\text {frame }}$ derived from ultrasonic data. Further, if the compressive strain is accumulated by pore-volume reduction, the time required for particles to reorganize and fluids to filtrate through the pore space would lead to an apparent stiffening of the material at higher strain rates. To account for these effects, the strain rate should be sufficiently low. On the other hand, the strain rate should be sufficiently high to avoid any creep effects occurring at lower stresses well within the elastic domain (Singh et al., 2017).

According to Biot (1941), the effective stress for elastic strain depends on the externally imposed hydrostatic stress $\sigma_{\text {hyd }}$, and pore pressure $P_{p}$ :

$$
\sigma_{\text {hyd }}^{\prime}=\sigma_{\text {hyd }}-\alpha P_{p}
$$

where $\alpha$ is Biot's coefficient. Equation 2 illustrates that in a porous material, the externally applied load is carried by the frame and a fraction $\alpha$ by the pore pressure. From Biot (1941), it is easy to derive the following expression:

$$
\alpha=1-\frac{K_{\text {bulk }}^{\text {frame }}}{K_{\min }},
$$

where $K_{\min }$ is the mineral bulk modulus and $K_{\text {bulk }}^{\text {frame }}$ is typically obtained from ultrasonic tests in which the dry density $\rho$, and elastic wave velocities $V_{\mathrm{P}}\left(\mathrm{P}\right.$-wave) and $V_{\mathrm{S}}(\mathrm{S}$-wave) of dry air-saturated samples using $K_{\text {bulk }}^{\text {frame }}=\rho\left(V_{\mathrm{P}}^{2}-4 V_{\mathrm{S}}^{2} / 3\right)$. When the imposed effective hydrostatic stress exceeds a threshold called yield stress, the initial predominantly linear elastic behavior becomes overshadowed by plastic deformation.

We envision that the elastic bulk modulus of a chalk frame depends on the degree of particle contact cementation and on electrostatic forces. Contact cement is initiated at particle contacts during the diagenetic transformation of carbonate ooze to chalk and cause induration (Fabricius, 2003) (Figure 1a). A probable mechanism initiating contact cementation is pressure dissolution. According to Croizè et al. (2010), pressure dissolution at calcite-calcite contacts requires $400 \mathrm{MPa}$. Such stresses may develop at particle contacts during early (200-300 m) burial of carbonate ooze at a high Biot's coefficient $(\geq 0.98)$ (Fabricius, 2014). Dissolved ions from stressed particle contacts precipitate onto unstressed regions nearby leading to coalescence of neighboring particles (Revil, 2001). Contact cementation involves perfectly matched crystal interfaces that are sufficiently close to each other $(<1-2 \mathrm{~nm})$ that intermolecular attractions occur, which are responsible for binding two adjacent calcite particles to each other (Van der Waals forces, Appendix A).

In addition to contact cementation, the surface charge has been inferred to have an impact on the mechanical behavior of high-porosity chalk (e.g., Megawati et al., 2013). These authors note that the 
cohesive force from Van der Waals attraction would be counteracted by the electrostatic repulsion between two adjacent surfaces charged due to adsorption of divalent anions. Even in pure water, calcite has a surface charge distribution, which can give rise to electrostatic repulsive forces (Risnes et al., 2005; Røyne et al., 2015).

The strength of the cohesive Van der Waals attraction and the electrostatic repulsion scales differently with respect to the distance because attraction dominates at short distances whereas repulsion dominates at intermediate distances. Figure 2a illustrates the side view of two neighboring calcite particles, which are held together by contact cementation allowing attractive Van der Waals forces, while being repelled by the electrostatic forces. The electrostatic repulsion and the Van der Waals attraction can be added together (Figure 2b). Note that the attractive forces have a minus sign, whereas the repelling forces have a plus sign, which is opposite of the convention in geotechnical engineering, where inward-directed forces are positive. The sum of the two effects is termed the disjoining pressure $P(d)$. A calculation of $P$ as function of the distance between two adjacent surfaces is shown in Appendix A with parameters in Table A-1. Whether attraction or repulsion dominates the overall behavior depends on the surface charge itself and the distance between the particle surfaces. We offer a phenomenological description of the underlying surface processes that are at play when brines of different composition saturate the chalk. On the contrary, for chalks not saturated with polar or electrolytic fluids, the electrostatic field is neutralized because a monolayer of water molecules neutralizes the positively and negatively charged sites on the $\{10-14\}$-form of the calcite rhombohedron (Stipp, 1999).

To find the electrostatic component of chalk strength and stiffness, we will in this paper show the results of 32 hydrostatic loading experiments on brine-saturated chalk, where ionic composition of brine and testing conditions are varied. Two tests on Soltrol oil-saturated chalk, where the electrostatic effects are minimized, were performed to have a comparative basis for brine-saturated tests.

\section{GEOLOGIC SAMPLES}

Liège chalk was used for the present study. It has been frequently used as an analog material to study the chemo-mechanical processes occurring in North Sea reservoir chalks. The sampled chalk belongs to the Cretaceous (Campanian to early Maastrichtian) Gulpen Formation and has silt- and fossil-bearing mudstone texture (Figure 1). Besides calcite, which represents the major mineralogical component ranging from $94 \%$ to $99 \%$, quartz, smectite, mica, kaolinite clinoptilolite, and traces of apatite, feldspar, pyrite, and titanium oxides may be found (Hjuler and Fabricius, 2009). For chalk samples from Liège, Hjuler and Fabricius (2009) find the Brunauer-Emmett-Teller (BET) specific surface area to be 1.7 and $3.4 \mathrm{~m}^{2} / \mathrm{g}$, as well as mineral density of $2.72 \mathrm{~g} / \mathrm{cm}^{3}$, Megawati et al. (2015) find carbonate content of $95 \%$ and specific surface of $3.9 \mathrm{~m}^{2} / \mathrm{g}$, whereas Andersen et al. (2017) find a mineral density of $2.69 \mathrm{~g} / \mathrm{cm}^{3}$ and a specific surface area of $2.7 \mathrm{~m}^{2} / \mathrm{g}$.

\section{METHODS}

\section{Sample preparation}

Cylindrical plugs were drilled from the Liegè chalk blocks before being radially adjusted and cut to the desired length. Before testing, the plugs were dried at $100^{\circ} \mathrm{C}$ overnight such that the dry mass could be measured. Ultrasonic velocities were measured on a single sample. The plugs were then cooled in a desiccator vacuum chamber and saturated with distilled water for wet weight measurement, and then dried again. The saturated minus the dry weight were used to quantify the pore volume and hence the saturation porosity. Two samples (acquired from a separate Liège block with similar porosity and mechanical behavior) were saturated with Soltrol oil, whereas 32 chalk samples were saturated with four different brines: synthetic seawater (SSW), 0.657 M NaCl, 0.219 $\mathrm{M} \mathrm{Na}_{2} \mathrm{SO}_{4}$, and $0.219 \mathrm{M}$ $\mathrm{MgCl}_{2}$ (Table 1, the recipe of each brine is shown in bold). Seawater was chosen because this is used for injection in oil reservoirs on the Norwegian Continental Shelf, such as the Ekofisk field, for pressure support and enhanced oil production purposes; $\mathrm{NaCl}$ was used because of the low degree of chemical reactions and adsorption/ desorption expected from the sodium or the chloride-ion, $\mathrm{Na}_{2} \mathrm{SO}_{4}$ was used because of the presence of the divalent anion $\left(\mathrm{SO}_{4}{ }^{2-}\right)$, and $\mathrm{MgCl}_{2}$ because of the divalent cation $\left(\mathrm{Mg}^{2+}\right)$. Sixteen of these samples were saturated the same day as they were mounted into triaxial cells. These 16 tests were termed the unaged samples, and the initial porosity $\left(\phi_{\text {ini }}\right.$, i.e., the porosity before the mechanical loading test)

a)

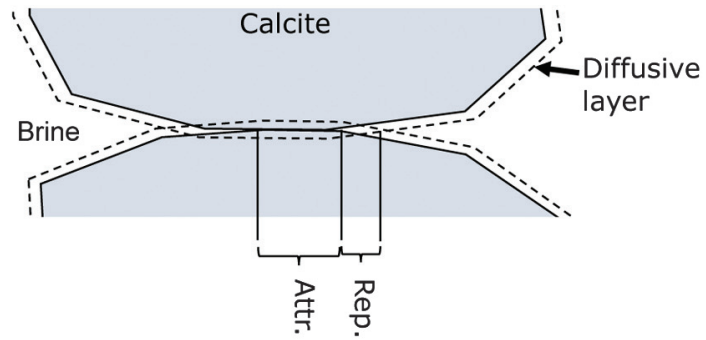

b)
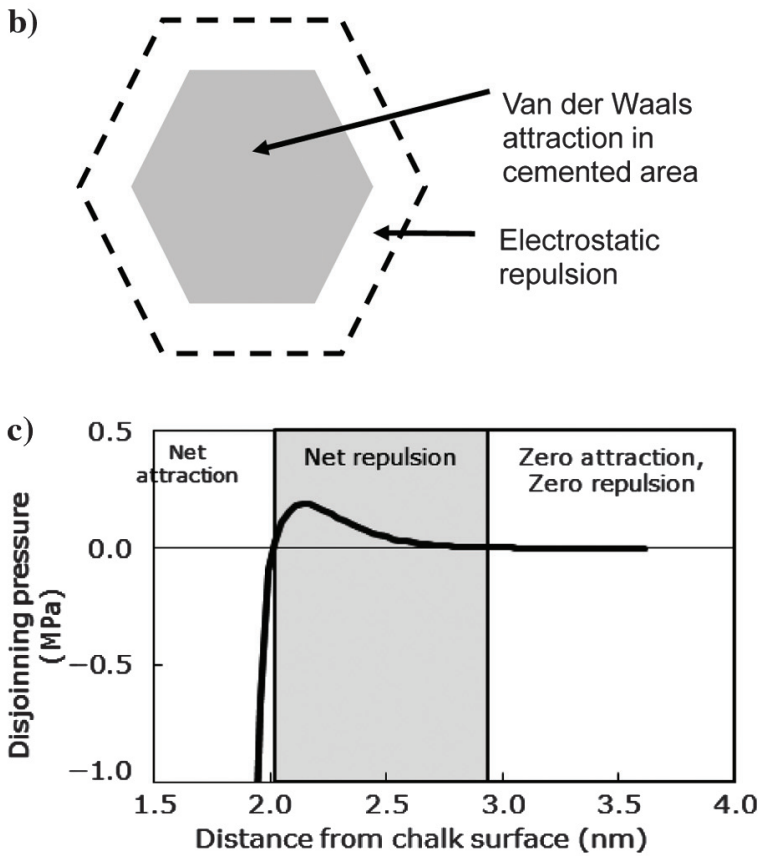

Figure 2. (a) A sketch of mechanisms responsible for binding neighboring calcite crystals together (side view). (b) Top-view of continuous contact cement (adhesive Van der Waals attraction) at short intergranular distances and repulsive disjoining forces at moderate distances between the neighboring grains $(2-3 \mathrm{~nm})$, where the diffusive layers overlap. (c) Estimated disjoining pressure as a function of distance between two neighboring surfaces. See Appendix A for details. 
was simply given by the saturation porosity. The other 16 samples were put in $120 \mathrm{~cm}^{3}$ aging cells and placed in a heating cabinet for three weeks at $130^{\circ} \mathrm{C}$ and a fluid pressure of $0.7 \mathrm{MPa}$ to avoid boiling, before they were cooled down and mounted into the triaxial cells. The initial porosity of these samples were given by an adjustment of the saturation porosity in which chemical calculations based ion chromatography analysis of effluent samples taken from the aging cells. Any change in fluid composition resulted from rock-fluid interactions between brines and chalk (see Table 2). The prolonged aging was done to make sure that the system attained equilibrium with respect to adsorption of anions/cations and to check directly if the weakening at $130^{\circ} \mathrm{C}$ is reversible for the samples mechanically tested at $23^{\circ} \mathrm{C}$.

\section{Loading experiments}

Loading experiments were performed at ambient temperature $\left(23^{\circ} \mathrm{C}\right)$ and at $130^{\circ} \mathrm{C}$, which is equivalent to the Ekofisk reservoir temperature. The overall test matrix for brine-saturated samples consists of two test temperatures, unaged or aged, and four brine compositions, i.e., a test matrix of $2 \times 2 \times 4=16$ tests. Each test was duplicated to check the reproducibility and to identify outliers, such that, in all, 32 mechanical loading experiments were performed on brine-saturated samples. In addition, two oil-saturated samples were tested in the triaxial cell at ambient temperature, in which the impact of electrostatic fields from the chalk surface is assumed to be negligible.

The experiments were performed in triaxial cells with continuous drainage from both ends. The axial length of the sample $L$ was measured via a linear voltage differential transducer placed on top of the moving piston. The cells were equipped with a heating jacket and regulating system (Omron E5CN), with precise temperature control $\left( \pm 0.1^{\circ} \mathrm{C}\right)$. The temperature was monitored by a Pt-100RDT resis- tance temperature detector placed inside the cell. Three Gilson pumps (Model 307 HPLC) were connected to the cell allowing independent control of the piston pressure $P_{\text {pist }}$, radial confining stress $P_{\mathrm{cf}}$, (i.e., the pressure in the confining oil), and injection flow rate $q_{\text {in }}$.

The axial stress $\sigma_{\mathrm{ax}}$ was calculated from $P_{\mathrm{cf}}$ and $P_{\text {pist }}$, as well as the hydraulic pressure required to overcome the piston friction $P_{\text {fric }}$, and an area factor $f$ relating the cross area of the piston to the cross area of the sample $(f=1.28$ was used):

$$
\sigma_{\mathrm{ax}}=P_{\mathrm{cf}}+f\left(P_{\mathrm{pist}}-P_{\text {fric }}\right) .
$$

The piston pressure was set to $0.2 \mathrm{MPa}$ above the measured friction to ensure piston movement as the plug compacted. The axial stress was therefore 0.25 MPa higher than the radial stress. Hydrostatic conditions were considered to be met above $5 \mathrm{MPa}$ confining pressure when the ratio of axial divided by radial stress became less than 1.05 . The samples were surrounded by a heat-activated shrinkage sleeve (polymer plastic) to separate the plug from the confining oil. Mechanical loading was performed by increasing $P_{\mathrm{cf}}$ continuously by injecting confining oil at a constant rate of $0.05 \mathrm{ml} / \mathrm{min}$. An injecting rate of $0.05 \mathrm{ml} / \mathrm{min}$ corresponds to a loading rate from 1.2 to $10.0 \mathrm{MPa}$ during $2 \mathrm{~h}$, which is a trade-off to avoid pore pressure build-up inside the sample and sufficiently fast to minimize the effect of time-dependent plastic compaction. The brine permeability of Liège chalk was reported by Andersen et al. (2017) to be 1.8 and $1.9 \mathrm{mD}$, whereas Nermoen et al. (2015) report it to be $1.1 \mathrm{mD}$.

The flow loop coupled to the triaxial cell was saturated with the test brine before the loading test started to ensure a constant brine composition. Brines were continuously injected into the flow loop with the bypass valve "open" to ensure zero pore-fluid pressure difference across the sample, and a backpressure regulator downstream ensured that the fluid pressure was maintained at $0.7 \mathrm{MPa}$. Each loading test that was performed at $23^{\circ} \mathrm{C}$ took one whole workday, whereas each test at $130^{\circ} \mathrm{C}$ took three days.

Table 1. Ionic composition of the original brine in which samples were submerged during aging and saturated during mechanical test are shown in bold. The associated brine composition of fluid samples after the aging (three weeks at $\left.130^{\circ} \mathrm{C}\right)$ are shown.

\begin{tabular}{|c|c|c|c|c|c|c|}
\hline $\begin{array}{l}\text { Sample ID and test } \\
\text { temperature }\end{array}$ & $\begin{array}{l}\text { Sodium } \mathrm{Na}^{+} \\
(\mathrm{mol} / \mathrm{l})\end{array}$ & $\underset{(\mathrm{mol} / \mathrm{l})}{\text { Potassium }} \mathrm{K}^{+}$ & $\underset{(\mathrm{mol} / \mathrm{l})}{\operatorname{Magnesium} \mathrm{Mg}^{2+}}$ & $\underset{(\mathrm{mol} / \mathrm{l})}{\mathrm{Calcium} \mathrm{Ca}^{2+}}$ & $\begin{array}{l}\text { Chloride } \mathrm{Cl}^{-} \\
\quad(\mathrm{mol} / \mathrm{l})\end{array}$ & $\begin{array}{l}\text { Sulfate } \mathrm{SO}_{4}{ }^{2-} \\
(\mathrm{mol} / \mathrm{l})\end{array}$ \\
\hline Orig. $\mathrm{NaCl}$ & 0.657 & $\mathbf{0}$ & $\mathbf{0}$ & $\mathbf{0}$ & 0.657 & 0 \\
\hline $\mathrm{L} 20-130^{\circ} \mathrm{C}$ & 0.627 & 0 & 0 & 0.014 & 0.658 & 0 \\
\hline $\mathrm{L} 22-130^{\circ} \mathrm{C}$ & 0.628 & 0 & 0 & 0.014 & 0.662 & 0 \\
\hline $\mathrm{L} 9-130^{\circ} \mathrm{C}$ & 0 & 0 & 0.174 & 0.038 & 0.444 & 0 \\
\hline $\mathrm{L} 12-23^{\circ} \mathrm{C}$ & 0 & 0 & 0.170 & 0.043 & 0.438 & 0 \\
\hline Orig. $\mathrm{Na}_{2} \mathrm{SO}_{4}$ & 0.438 & $\mathbf{0}$ & $\mathbf{0}$ & $\mathbf{0}$ & $\mathbf{0}$ & 0.219 \\
\hline $\mathrm{L} 17-130^{\circ} \mathrm{C}$ & 0.384 & 0 & 0 & 0.011 & 0 & 0.203 \\
\hline $\mathrm{L} 10-130^{\circ} \mathrm{C}$ & 0.412 & 0 & 0 & 0.006 & 0 & 0.210 \\
\hline $\mathrm{L} 31-23^{\circ} \mathrm{C}$ & 0.443 & 0.0076 & 0.0134 & 0.047 & 0.525 & 0.015 \\
\hline
\end{tabular}


During hydrostatic stress buildup, the axial $\varepsilon_{\mathrm{ax}}$ strains were measured from the change in length divided by the initial length, $\varepsilon_{\mathrm{ax}}=-\Delta L / L_{0}$. Typically, at hydrostatic stress conditions, the sample does not keep its cylindrical geometry during loading even when the material is nearly isotropic (Nermoen et al., 2015), an effect most likely originating from the boundary conditions imposed by the steel end pieces on both ends of the sample (Nermoen et al., 2016). This leads to a larger radial strain at the center of the sample than at the ends, where negligible radial strain is seen. Under the assumption that the total bulk volume change is proportional to the axial deformation, we set the volumetric strain $\varepsilon_{\mathrm{vol}}=3 \varepsilon_{\mathrm{ax}}$ for all experimental analyses. This is likely an overestimate of $\varepsilon_{\mathrm{vol}}=3 \varepsilon_{\mathrm{ax}}$ leading to a too-low bulk modulus estimate. The imposed error is systematic for all tests enabling an internally consistent comparison. To calculate the porosity evolution during compaction the following relation was used:

$$
\phi=\frac{\phi_{\text {init }}-\varepsilon_{\mathrm{vol}}}{1-\varepsilon_{\mathrm{vol}}} .
$$

\section{Fluid sampling}

Fluid samples were collected directly from the $(120 \mathrm{ml})$ aging cells of the brines surrounding the samples after three weeks at $130^{\circ} \mathrm{C}$. The fluid samples were diluted 500 times with distilled water using a Gilson GX-271 machine to meet the linear region of the calibration curve of the Dionex ICS-3000 chromatograph. The concentration of four anions and three cations were estimated using the IonPac AS16 and IonPac CS12A exchange column, respectively. Each concentration was quantified from the area under the chromatographic curve compared with known standards. Table 1 reports the concentrations of four cations (sodium, potassium, magnesium, and calcium) and two anions (chloride and sulfate). The values can be compared with the original values shown in bold (Table 1). Because the fluid concentrations are given and the volume of the cell, the bulk volume of each sample, and the porosity are known, we may quantify the amount of dissolution/precipitation that occurred in the sample (Table 2).

Table 2. Interpretation of adsorption and precipitation/dissolution processes based on chemical and petrophysical data. Chemical changes in brines surrounding the cores after three weeks of aging at $130^{\circ} \mathrm{C}$.

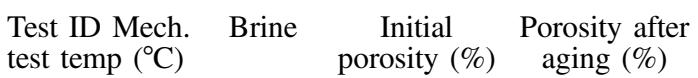

Internal surface

Change after aging

$\begin{array}{lllll}\left(\mathrm{m}^{2}\right) & \text { Numb. sites }\left(10^{18}\right) & \mathrm{Mg}^{2+}(\mathrm{mmol}) & \mathrm{Ca}^{2+}(\mathrm{mmol}) & \mathrm{SO}_{4}{ }^{2-}(\mathrm{mmol})\end{array}$

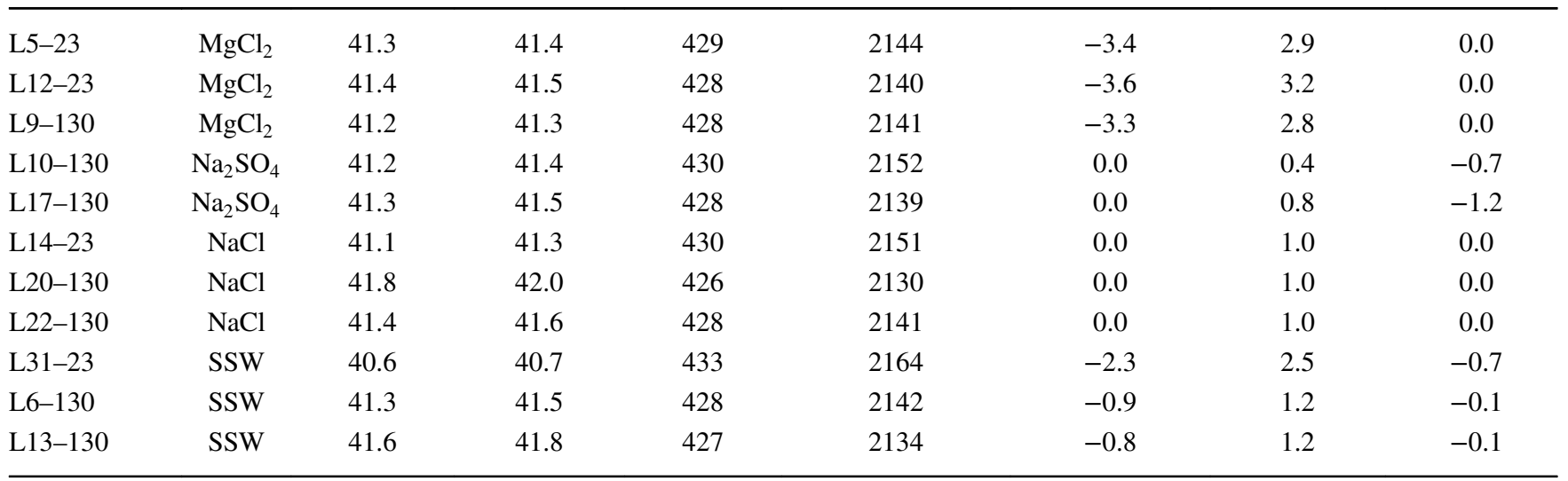

Adsorbed molecules

Precipitated

Dissolved



\begin{tabular}{|c|c|c|c|c|c|c|c|c|}
\hline L5-23 & $\mathrm{MgCl}_{2}$ & 1072 & - & - & 1.6 & 0.10 & 4.4 & 0.16 \\
\hline L12-23 & $\mathrm{MgCl}_{2}$ & 1070 & - & - & 1.8 & 0.12 & 5.0 & 0.18 \\
\hline L9-130 & $\mathrm{MgCl}_{2}$ & 1071 & - & - & 1.5 & 0.10 & 4.3 & 0.16 \\
\hline L10-130 & $\mathrm{Na}_{2} \mathrm{SO}_{4}$ & - & 395 & 2152 & - & - & 4.0 & 0.15 \\
\hline L17-130 & $\mathrm{Na}_{2} \mathrm{SO}_{4}$ & - & 703 & 2139 & 一 & - & 4.4 & 0.16 \\
\hline L14-23 & $\mathrm{NaCl}$ & - & - & 2151 & - & - & 4.5 & 0.17 \\
\hline L20-130 & $\mathrm{NaCl}$ & - & - & 2130 & - & - & 4.6 & 0.17 \\
\hline L22-130 & $\mathrm{NaCl}$ & - & - & 2141 & - & - & 4.6 & 0.17 \\
\hline L31-23 & SSW & 1082 & 392 & - & 0.5 & 0.03 & 2.9 & 0.11 \\
\hline L6-130 & SSW & 554 & 88 & 1034 & - & - & 2.9 & 0.11 \\
\hline L13-130 & SSW & 489 & 44 & 1156 & - & - & 3.2 & 0.12 \\
\hline
\end{tabular}




\section{RESULTS}

\section{Bulk moduli and yield strength}

Mechanical loading test results for the brine-saturated samples were compared with results from tests on oil-saturated samples by plotting stress-strain curves (Figure 3a-3f). Figure 3a-3d shows the loading curves of chalk saturated with seawater, $\mathrm{NaCl}$ brine,
$\mathrm{Na}_{2} \mathrm{SO}_{4}$ brine, and $\mathrm{MgCl}_{2}$ brine, respectively. In Figure 3e, the unaged oil-saturated samples tested at $23^{\circ} \mathrm{C}$ are shown. A straight line was fitted to the initial stage of each loading curve enabling the determination of the drained bulk modulus $K_{\text {drained }}$. The value of $K_{\text {drained }}$ for each experiment was only obtained from the initial linear part of the stress-strain curves (Figure 3). Hydrostatic loading further, the stress-strain data curved until a new linear behavior was

Table 3. Brine composition, testing temperature, aging or no aging, as well as bulk modulus $\left(K_{\text {drained }}\right)$ and onset of yield from mechanical testing. Initial porosity originate from saturation tests, porosity after aging are calculated in Table 2 , and porosity at onset of yield $\left(\phi_{y}\right)$ is estimated from the strain at yield, $\phi_{y}=\left(\phi_{a}-\varepsilon_{\mathrm{vol}, y}\right) /\left(1-\varepsilon_{\mathrm{vol}, y}\right)$ during loading.

\begin{tabular}{|c|c|c|c|c|c|c|c|c|c|c|}
\hline Brine & $\begin{array}{l}\text { Temp } \\
\left({ }^{\circ} \mathrm{C}\right)\end{array}$ & Aging & ID L\# & $\begin{array}{c}\text { Bulk mod., } \\
K_{\text {drained }}(\mathrm{GPa})\end{array}$ & $\begin{array}{c}\text { Onset of } \\
\text { yield (MPa) }\end{array}$ & $\begin{array}{l}\text { Pragm. Yield } \\
\text { (MPa) }\end{array}$ & $\begin{array}{c}\text { Full yield } \\
(\mathrm{MPa})\end{array}$ & $\begin{array}{c}\text { Initial } \\
\text { porosity }(\%)\end{array}$ & $\begin{array}{c}\text { Porosity } \\
\text { after } \\
\text { aging (\%) } \\
\end{array}$ & $\begin{array}{c}\text { Porosity at } \\
\text { onset of } \\
\text { yield (\%) } \\
\end{array}$ \\
\hline \multirow[t]{8}{*}{$\mathrm{NaCl}$} & \multirow[t]{4}{*}{130} & \multirow[t]{2}{*}{ Yes } & L20 & $0.74 \pm 0.03$ & 5.8 & 7.0 & 8.0 & 41.8 & 42.0 & 41.5 \\
\hline & & & L22 & $0.83 \pm 0.02$ & 6.1 & 7.2 & 8.3 & 41.4 & 41.6 & 41.2 \\
\hline & & \multirow[t]{2}{*}{ No } & L38 & $1.02 \pm 0.03$ & 5.4 & 6.5 & 8.4 & 41.2 & - & 40.9 \\
\hline & & & L39 & $0.85 \pm 0.01$ & 6.2 & 7.2 & 8.1 & 41.2 & - & 40.8 \\
\hline & \multirow[t]{4}{*}{23} & \multirow[t]{2}{*}{ Yes } & ${\mathrm{L} 33^{6}}^{6}$ & $1.00 \pm 0.02$ & 6.3 & 7.1 & 8.1 & 40.5 & 40.7 & 40.4 \\
\hline & & & L14 & $0.89 \pm 0.02$ & 6.0 & 6.2 & 6.9 & 41.1 & 41.3 & 40.9 \\
\hline & & \multirow[t]{2}{*}{ No } & L15 & $0.84 \pm 0.04$ & 7.5 & 8.0 & 8.8 & 41.1 & - & 40.6 \\
\hline & & & L27 & $1.07 \pm 0.03$ & 6.3 & 7.2 & 8.8 & 41.0 & - & 40.6 \\
\hline \multirow[t]{8}{*}{$\mathrm{Na}_{2} \mathrm{SO}_{4}$} & \multirow[t]{4}{*}{130} & \multirow[t]{2}{*}{ Yes } & L10 & $0.48 \pm 0.01$ & 4.5 & 5.1 & 5.6 & 41.2 & 41.4 & 40.9 \\
\hline & & & L17 & $0.43 \pm 0.02$ & 4.1 & 4.4 & 5.3 & 41.3 & 41.5 & 41.0 \\
\hline & & \multirow[t]{2}{*}{ No } & L28 & $0.52 \pm 0.03$ & 4.5 & 5.6 & 6.4 & 40.8 & - & 40.3 \\
\hline & & & L30 & $0.55 \pm 0.02$ & 5.1 & 5.6 & 6.4 & 40.6 & - & 40.1 \\
\hline & \multirow[t]{4}{*}{23} & \multirow[t]{2}{*}{ Yes } & $\mathrm{L} 16^{6}$ & $0.59 \pm 0.02$ & 5.3 & 5.6 & 6.3 & 41.2 & 41.4 & 40.9 \\
\hline & & & $\mathrm{L} 24^{6}$ & $0.47 \pm 0.01$ & 5.5 & 5.8 & 6.4 & 41.1 & 41.3 & 40.7 \\
\hline & & \multirow[t]{2}{*}{ No } & L26 & $0.97 \pm 0.01$ & 6.1 & 6.7 & 7.6 & 41.3 & - & 40.9 \\
\hline & & & L29 & $1.02 \pm 0.18$ & 7.1 & 7.6 & 8.6 & 41.2 & - & 40.8 \\
\hline \multirow[t]{8}{*}{$\mathrm{MgCl}_{2}$} & \multirow[t]{4}{*}{130} & \multirow[t]{2}{*}{ Yes } & $\mathrm{L} 4^{6}$ & $0.70 \pm 0.03$ & 5.7 & 7.1 & 8.1 & 41.3 & 41.4 & 41.0 \\
\hline & & & L9 & $0.75 \pm 0.03$ & 6.3 & 6.9 & 7.9 & 41.2 & 41.3 & 40.9 \\
\hline & & \multirow[t]{2}{*}{ No } & $\mathrm{L} 8^{4}$ & $0.54 \pm 0.05$ & 3.4 & 4.3 & 6.3 & 43.3 & - & 43.0 \\
\hline & & & L37 & $0.86 \pm 0.06$ & 5.3 & 6.4 & 8.1 & 41.8 & - & 41.5 \\
\hline & \multirow[t]{4}{*}{23} & \multirow[t]{2}{*}{ Yes } & $\mathrm{L}^{4}$ & $1.16 \pm 0.02$ & 6.2 & 6.6 & 7.2 & 41.3 & 41.4 & 41.1 \\
\hline & & & L12 & $0.78 \pm 0.02$ & 6.9 & 7.9 & 8.7 & 41.4 & 41.5 & 40.9 \\
\hline & & \multirow[t]{2}{*}{ No } & L7 & $0.95 \pm 0.06$ & 7.3 & 7.9 & 8.7 & 41.3 & - & 40.9 \\
\hline & & & L18 & $0.96 \pm 0.03$ & 7.2 & 7.8 & 8.8 & 41.3 & - & 40.9 \\
\hline \multirow[t]{8}{*}{ SSW } & \multirow[t]{4}{*}{130} & \multirow[t]{2}{*}{ Yes } & L6 & $0.48 \pm 0.02$ & 5.7 & 6.4 & 7.1 & 41.3 & 41.5 & 40.9 \\
\hline & & & L13 & $0.54 \pm 0.03$ & 5.5 & 6.0 & 6.9 & 41.6 & 41.8 & 41.3 \\
\hline & & \multirow[t]{2}{*}{ No } & L34 & $0.61 \pm 0.02$ & 5.2 & 5.4 & 6.4 & 41.8 & - & 41.4 \\
\hline & & & L35 & $0.64 \pm 0.04$ & 5.4 & 5.8 & 7.1 & 41.3 & - & 40.8 \\
\hline & \multirow[t]{4}{*}{23} & Yes & $\mathrm{L} 32^{6}$ & $0.79 \pm 0.05$ & 6.2 & 6.8 & 8.2 & 40.3 & 40.5 & 40.1 \\
\hline & & & L31 & $0.83 \pm 0.02$ & 6.2 & 7.1 & 8.4 & 40.6 & 40.7 & 40.2 \\
\hline & & No & L19 & $1.07 \pm 0.04$ & 7.9 & 8.2 & 9.2 & 41.1 & - & 40.7 \\
\hline & & & L25 & $1.11 \pm 0.05$ & 6.3 & 7.0 & 8.8 & 41.6 & - & 41.3 \\
\hline Oil & 23 & No & $\mathrm{LO}^{5}$ & $1.22 \pm 0.02$ & 17.8 & 20.6 & 25.1 & 40.9 & - & 39.9 \\
\hline & & & $\mathrm{LO}_{1} 1^{5}$ & $1.43 \pm 0.03$ & 17.8 & 22.7 & 25.2 & 40.3 & - & 39.3 \\
\hline
\end{tabular}

${ }^{4}$ Outlier sample with higher porosity.

${ }^{5}$ Oil-saturated cores acquired from a different Liegè block.

${ }^{6}$ Assumed porosity after aging because of lack of fluid chromatography data. 
observed. From the secondary linear region (less steep than the initial region), the plastic modulus was obtained. The straight dashed lines in Figure $3 \mathrm{e}$ and $3 \mathrm{f}$ exemplify the determination of the drained bulk modulus and plastic modulus for four different tests saturated by oil and SSW. The change from the initial linear elastic behavior to the secondary linear plastic behavior was characterized using three stresses: (1) onset of yield, (2) pragmatic yield, and (3) full yield. These stresses are related to pore collapse of the sample, in which volumetric compaction is accommodated by pore-volume reduction. When the observed stress-strain curve deviated more than $0.3 \mathrm{MPa}$ from the initial linear behavior, the stress at onset of yield was determined. In the same way, full yield was found by comparing with the onset of linear plasticity. The pragmatic yield stress in the middle occurred at the strain when the linear elastic and linear plastic lines intercept (red square in Figure 3e and 3f). The values of the initial elastic bulk drained modulus, the onset, pragmatic and full yield, and corresponding porosities are illustrated in Figure 3e and $3 \mathrm{f}$ and reported in Table 3 .

The oil-saturated samples are stiffer and have higher yield stress than the brine-saturated samples (Figure 3). The average frame bulk modulus of the two oil-saturated samples tested in static triaxial tests at drained conditions was found to be $K_{\text {drained }}=1.33 \mathrm{GPa}$ (average of 1.22 and $1.43 \mathrm{GPa}$ of the two tests shown in Table 3 ). From equation 3 , we obtain $\alpha=0.98$ using $75 \mathrm{GPa}$ as the elastic bulk modulus of calcite. We can then from equation 2 calculate the effective stress $\sigma^{\prime}$ for all tests. From dynamic ultrasonic velocity test (very low strain amplitude) on a dry sample, we obtain $K_{\text {bulk }}^{\text {frame }}=2.77 \mathrm{GPa}$, corresponding to $\alpha=0.96$.

In Figure 4, we plot the results of the triaxial tests with $K_{\text {drained }}$ along the $x$-axis and the pragmatic yield stress $Y_{p}$ along the $y$-axis for all 32 brine-saturated samples. $K_{\text {drained }}$ and $Y_{p}$ are only weakly correlated, but a linear relation can still be constructed with a coefficient of determination $R^{2}=0.45$ ( $n=32$ ) (Figure 4a). The samples saturated with seawater are distributed along the trend line from the "soft-weak" quadrant to the "stiff-strong" quadrant of the plot. This is not the case with the NaCl-tests because all these samples tend to be found in the stiff-strong quadrant, and not elsewhere. Samples saturated with $\mathrm{Na}_{2} \mathrm{SO}_{4}$-brine tend to be soft and weak dependent upon aging and temperature. The two $\mathrm{Na}_{2} \mathrm{SO}_{4}$-tests found in the stiff-strong quadrant were unaged and mechanically tested at $23^{\circ} \mathrm{C}$ exemplifying when sulfate weakening does not occur. The samples saturated by $\mathrm{MgCl}_{2}$-brine tend also to behave stiff and have a relatively high yield stress for a given $K_{\text {drained }}$. The $\mathrm{MgCl}_{2}$ outlier test (L8), had an initial porosity of $43.3 \%$, whereas the rest of the samples had a porosity in the range $41.4 \% \pm 0.5 \%$, indicating how larger porosity variations are affecting mechanical stiffness and strength (see Table 3).

Figure $4 \mathrm{~b}$ discriminate between the same tests performed at $23^{\circ} \mathrm{C}$ and $130^{\circ} \mathrm{C}$. As can be seen, low and high temperature experiments can be found in the soft-weak and stiff-strong quadrant. The convex hulls, encapsulating all the scattered data-points, are used to visualize how the test temperature impacts the stiffness and strength. As can be seen, only about half the areas spanned by the two convex hull for the two temperatures overlaps. In addition, the frequency of soft-weak experiments is higher for high temperature than low, displaying the tendency that the lower temperature tests give rise to a stiffer and stronger chalk behavior.

In Figure 4c, the pragmatic yield stress and bulk modulus are plotted while discriminating between aging and no aging. Here, the areas spanned by the convex hull of the aged and unaged tests overlap more than in Figure 4b, although the number of aged samples in the soft-weak quadrant is higher than the number of unaged samples (and vice versa in the stiff-strong quadrant). Because the areas spanned by the convex hull overlap less when discriminating with a)
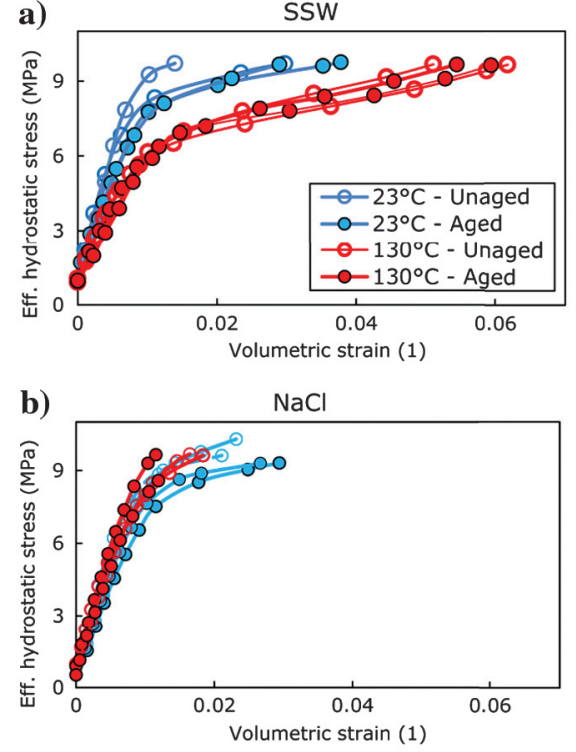

c)



d)

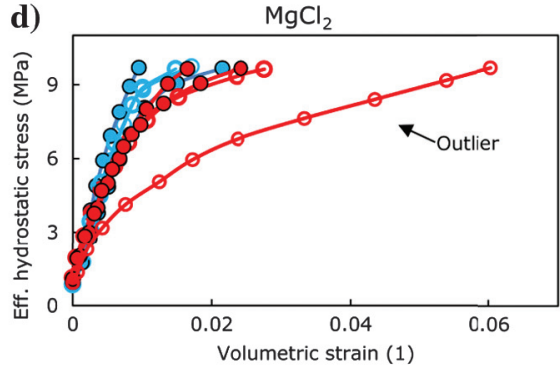

e)

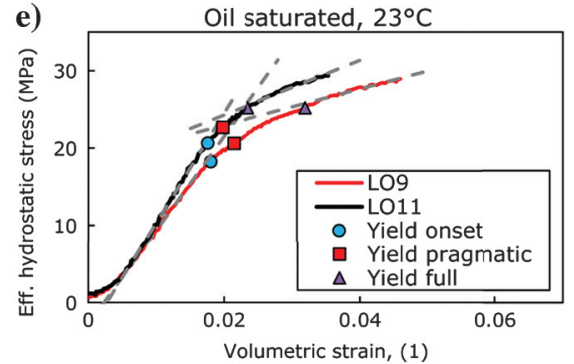

f)

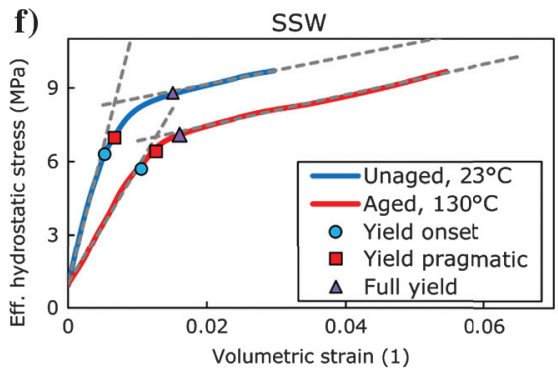

Figure 3. Effective hydrostatic stress versus volumetric strain of all tests $\left(23^{\circ} \mathrm{C}\right.$ and $130^{\circ} \mathrm{C}$, aged and unaged, four brines and two oil-saturated samples). Unaged samples are shown with open circles, and red color displays the $130^{\circ} \mathrm{C}$ tests. Saturated brines are (a) seawater (SSW), (b) $\mathrm{NaCl}$ brine, (c) $\mathrm{Na}_{2} \mathrm{SO}_{4}$ brine, and (d) $\mathrm{MgCl}_{2}$ brine. (e) Loading curves for two oil-saturated chalk test. Deviations from the initial elasticity are shown as the onset of yield (blue circle), pragmatic yield (red square), and full yield (purple triangle). The slopes of the dashed gray lines are used as bulk modulus in the elastic and plastic phase. (f) Illustrative example comparing two SSW brine-loading tests of an aged core at $130^{\circ} \mathrm{C}$ and an unaged core at $23^{\circ} \mathrm{C}$. 
respect to test temperature (Figure $4 b$ ) than to aging (Figure $4 c$ ), the test temperature is more important than aging to control stiffness and strength. The chemical effects associated with aging from the ion-chromatography data in Table 1 show the fluids to be enriched in calcium, whereas $\mathrm{Mg}^{2+}$ was depleted in the $\mathrm{Mg}^{2+}$-bearing brines. In addition, sulfate was depleted in the $\mathrm{SO}_{4}{ }^{2-}$-bearing brines.
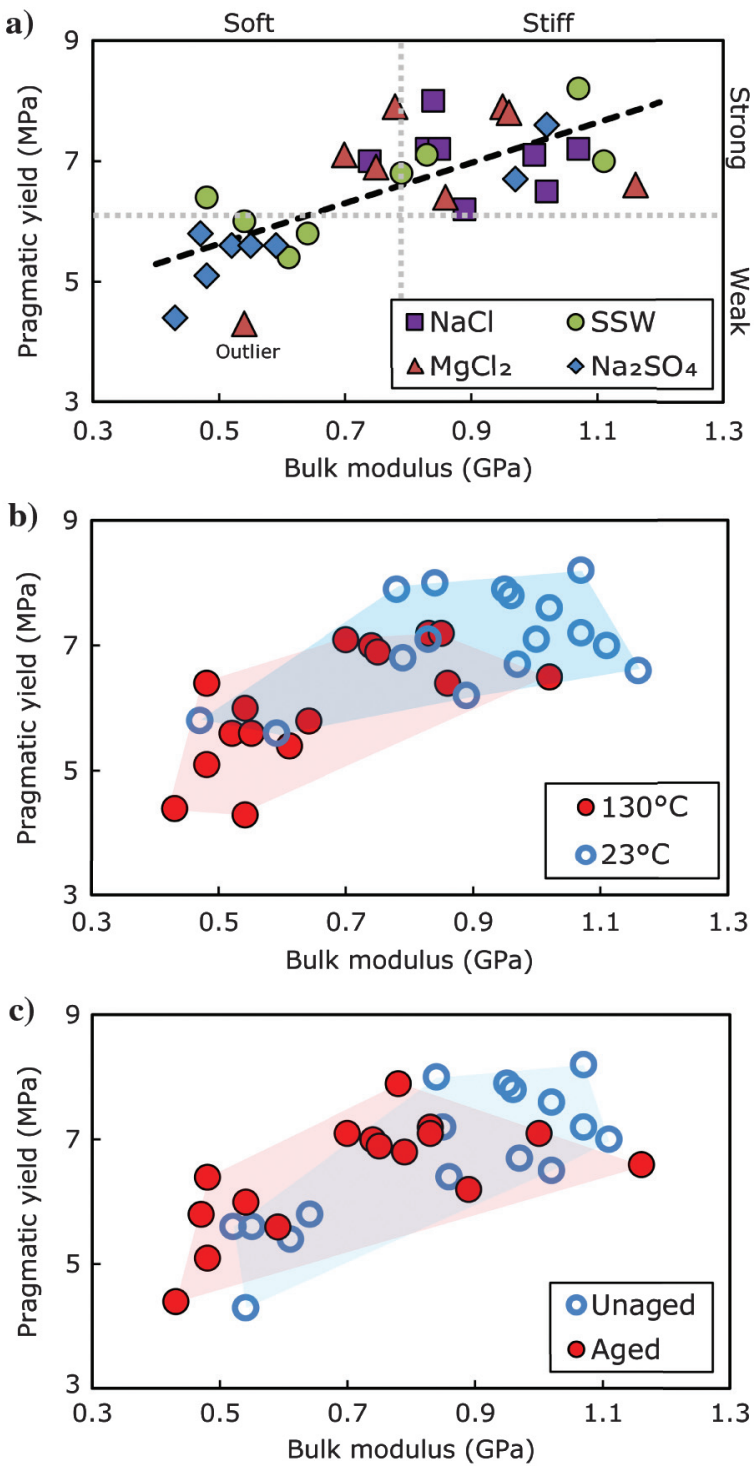

Figure 4. Pragmatic yield stress (strength, red squares in Figure $3 \mathrm{e}$ and 3f) versus bulk modulus (stiffness) for chalk saturated with four different brines, mechanically tested at $23^{\circ} \mathrm{C}$ and $130^{\circ} \mathrm{C}$. Cores were aged or unaged prior to tests. (a) Results discriminating with respect to the saturating brine: seawater (SSW), $\mathrm{NaCl}, \mathrm{Na}_{2} \mathrm{SO}_{4}$, and $\mathrm{MgCl}_{2}$ brines. The strength is correlated to stiffness as shown with the solid line as given by: $Y_{p}=3.5 K_{b}+4.0$, with $R^{2}=0.48$ for the $n=32$ tests. (b) Strength and stiffness with respect to test temperature. The $130^{\circ} \mathrm{C}$ tests occur more frequently in the soft-weak quadrant than tests at $23^{\circ} \mathrm{C}$. (c) Results from the aged and unaged tests. Unaged tests are more frequently found in the stiff-strong quadrant. For comparison, the bulk modulus and pragmatic yield of the oil-saturated cores were 1.2 and $1.4 \mathrm{GPa}$ and 20.6 and $23.7 \mathrm{MPa}$. Shaded regions in (b and c) display the convex hull. Vertical and horizontal error bars are displayed in Figure 5.
Patterns in mechanical behavior can thus be seen in Figure 4 with respect to (a) brine composition, (b) temperature, (c) as well as aging, indicating that it is a combination of effects that determines the mechanical behavior during loading. This is also illustrated in Figure 5, in which the mechanical results of pragmatic yield and bulk modulus are shown according to the brine composition. Here, the vertical and horizontal error bars are given. The error associated with strength (vertical) comes from the curved region of the loading curves seen in Figure 2, where the lower error bar represents the onset of yield and the upper error bar the stress at which full yield has occurred. The horizontal error bars represent the error of the initial slope obtained by the LINEST function of Excel (Figure 3). In Figure 5a, the seawater tests are shown. Here, the unaged samples at $23^{\circ} \mathrm{C}$ behave stiffly, the aged samples at $23^{\circ} \mathrm{C}$ show intermediate stiffness whereas aged, as well as unaged, samples were soft and weak when mechanically tested at $130^{\circ} \mathrm{C}$. It is interesting to note how the aged samples, tested at $23^{\circ} \mathrm{C}$ are found halfway between the unaged $23^{\circ} \mathrm{C}$ tests and the tests performed at $130^{\circ} \mathrm{C}$ indicating that the weakening is partially permanent with regard to aging. In Figure $5 \mathrm{~b}$, the results from the $\mathrm{NaCl}$ tests are shown. These samples are all moderately strong and stiff, with no clear significant pattern with respect to neither test temperature nor aging/unaging. Figure $5 \mathrm{c}$ displays $\mathrm{Na}_{2} \mathrm{SO}_{4}$ test results in which all samples tend to have a lowered yield stress relative to the trend line in Figure $3 \mathrm{a}$ and only the unaged samples at $23^{\circ} \mathrm{C}$ display a high stiffness and strength, and the remaining samples are soft. On the contrary to SSW-brine, the aged cores tested at $23^{\circ} \mathrm{C}$ coincide with the high-temperature tests indicating that aging at $130^{\circ} \mathrm{C}$ leads to full weakening and that the weakening is permanent. Figure $5 \mathrm{~d}$ represents samples with $\mathrm{MgCl}_{2}$-brine. All samples have relatively high yield stress and high bulk modulus, although samples tested at $130^{\circ} \mathrm{C}$ tend to be weaker than the $23^{\circ} \mathrm{C}$ tests. The yield stresses and drained bulk modulus for all tests are given in Table 3 .

Porosity impacts the mechanical properties of chalks. In Figure $6 \mathrm{a}$, the relation between the bulk modulus and porosity before the mechanical loading $\left(\phi_{\text {init }}\right)$ test is shown. The value of $\phi_{\text {init }}$ for the unaged samples is derived from the saturated porosity estimate (Table 3). The repeatability of this procedure is typically within $\pm 0.05 \%$. Nermoen et al. (2015) compare saturation porosity to helium adsorption pycnometry tests of the solid volume for the same Liège chalk. They showed that the weight-difference method underestimates the porosity by 0.4 percent units (p.u.), corresponding to a density difference of $0.02 \mathrm{~g} / \mathrm{cm}^{3}$. To determine $\phi_{\text {init }}$ for the aged samples, the saturation porosity measurements were adjusted by the solid volume change calculated from the ion chromatography (IC) data because of rock-fluid interactions (see Table 2). The uncertainty of these estimates was added to the uncertainty of the saturation porosity, such that an error of $\pm 0.1 \%$ is given for the initial porosity of the aged samples. All initial porosities before the mechanical loading are reported in Table 3. The dashed line in Figure $6 \mathrm{a}$ indicates a negative trend, although the coefficient of determination is only 0.06 , which is considered to be too low to claim that porosity plays a significant role in the elastic stiffness compared with the experimental parameters (test temperature, aging, and brine composition) for the porosity range reported here.

In Figure 6b, the onset of yield is shown as function of the porosity at yield. The porosity at the onset of yield $\phi_{y}$ was calculated from the volumetric strain using equation 5 . An additional uncertainty of $\pm 0.1 \%$ was added to the initial porosity estimate. For these 
porosities, a variation of $\pm 0.1 \%$ corresponds to a $5 \%$ uncertainty in the volumetric strain. The dashed line represents the negative correlation between $\phi_{y}$ and onset of yield, with a coefficient of determination of 0.16 implying that porosity at yield is not the most important factor in determining the strength of chalks studied here. Correlations between porosity and drained bulk modulus and yield strength are reported in the figure caption.

\section{DISCUSSION}

\section{Chemical reactions during aging}

As shown above each discriminating factor (temperature, aging, brine composition, and porosity) cannot alone dictate the elastic stiffness and mechanical strength of porous Liège chalk. A combination of effects is required to predict its mechanical behavior. Two chemical mechanisms are sufficient to describe the change in the fluid composition:

(1) Chemical reactions between the brine and the chalk surface related to dissolution and precipitation.

(2) Adsorption of surface-active divalent ions (sulfate, calcium, and magnesium). In the closed system of the experiments in question, the carbonate in solution will almost exclusively be in the form of monovalent bicarbonate (Madsen, 2002). On the typical calcite form $\{10-14\}$, there is an equal number of positive and negative sites, each with a charge of $1 / 3$ or $-1 / 3$ (Stipp, 1999).

Both mechanisms are, in our case, limited by the transport of ions in the chalk because the samples were not flooded but were submerged in a chamber during aging, by the rate of the proposed chemical reaction, and by the size of the fluid reservoir with reactive brine. Comparison of the original pore-fluid composition with the composition after aging (Tables 1 and 2) indicates that dissolution/precipitation and adsorption mechanisms are at play. Mechanism (1): In all cases, irrespective of brine composition, $\mathrm{Ca}^{2+}$ increases during aging. This would indicate chemical equilibration between the calcite and the pore water; however, fluids have different resulting $\mathrm{Ca}^{2+}$ concentration indicating that dissolution of calcite is not the sole mechanism controlling the calcium in the pore water. The depletion in $\mathrm{Mg}^{2+}$ in the pore waters is sufficiently high to conclude that $\mathrm{Mg}$-bearing carbonates may have precipitated (Table 2) similarly to what was indicated by X-ray diffraction and scanning electron microscopy with energy dispersive spectroscopy analysis after $\mathrm{MgCl}_{2}$ flow through experiments (Madland et al., 2011; Megawati et al., 2015).

Mechanism (2): In a chalk sample saturated with pure water, calcite will dissolve, and a part of the released $\mathrm{Ca}^{2+}$ will adsorb on the internal surface with a theoretical maximum of $8 \mu \mathrm{mol} / \mathrm{m}^{2}$ corresponding to five sites per $\mathrm{nm}^{2}$ (Huang et al., 1991). Several authors have found that $\mathrm{Mg}^{2+}$ and $\mathrm{SO}_{4}{ }^{2-}$ adsorb on calcite; in the case of $\mathrm{Mg}^{2+}$ leading to desorption of $\mathrm{Ca}^{2+}$ from the internal surface (e.g., Ahsan and Fabricius, 2010; Alam et al., 2010; Megawati et al., 2013).

To estimate if the drop in $\mathrm{Mg}^{2+}$ concentration could in addition to adsorption processes be caused by precipitation of Mg-bearing carbonates, we quantify the number of adsorption sites from BET analysis, porosity, and sample size (Table 2). We assume a BET value of $3.4 \mathrm{~m}^{2} / \mathrm{g}$ and five negative adsorption sites per $\mathrm{nm}^{2}$, and we also assume that $\mathrm{Mg}^{2+}$ (probably due to its large hydrated size) as found by Alam et al. (2010) only adsorbs to half the negative sites. By this method, we find that Mg-bearing carbonate should indeed precipitate in four of the tested samples because adsorption is insufficient to explain the Mg-depletion in the brine (Table 2). The drop in sulfate is in both cases below what is required for covering of half of the available positive sites (Table 2). As such, surface adsorption of sulfate is adequate to explain the loss, implying that no precipitation of sulfate salts is anticipated. If we assume that the negative adsorption sites are covered preferably by $\mathrm{Mg}^{2+}$ (each hydrated $\mathrm{Mg}^{2+}$ is shielding two sites) and the remaining sites are covered by $\mathrm{Ca}^{2+}$, we can calculate the total amount of dissolved calcite and precipitated dolomite and thus estimate the porosity increase caused by aging (Table 2). This enables us to estimate the change in the solid volume, and we find that the porosity increase due to chemical reactions in all cases is less than 0.2 p.u.

\section{Effect of brine on bulk modulus and yield strength}

The electrostatic repulsion expected between calcite particles in an aqueous solution causes the chalk to be weaker and softer than when saturated with oil. The electrostatic repulsion in chalk saturated by freshwater or $\mathrm{NaCl}$-brine would then be due to adsorbed positive divalent calcium ions. When the chalk is saturated with $\mathrm{MgCl}_{2}$-brine, it behaves relatively stiff and strong compared with when saturated with the other brines (Figure 4). This can be
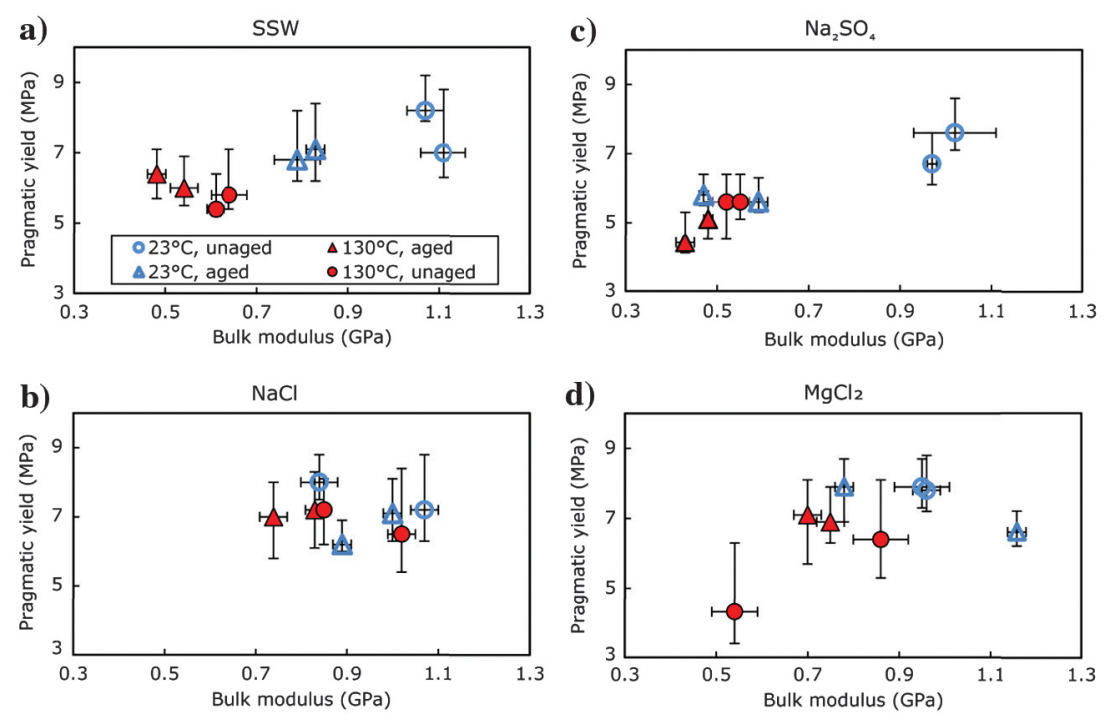

Figure 5. Pragmatic yield (red squares in Figure $3 \mathrm{e}$ and $3 \mathrm{f}$ ) stress versus drained bulk modulus for aged and unaged samples tested at $23^{\circ} \mathrm{C}$ and $130^{\circ} \mathrm{C}$. Saturation fluids are (a) seawater (SSW) brine, (b) $\mathrm{NaCl}$ brine, (c) $\mathrm{Na}_{2} \mathrm{SO}_{4}$ brine, and (d) $\mathrm{MgCl}_{2}$ brine. The lower vertical error bars display the onset of yield (blue circle in Figure $3 \mathrm{e}$ and $3 \mathrm{f}$ ), and the upper error bars display the stress at which full yield is observed (purple triangle in Figure $3 \mathrm{e}$ and $3 \mathrm{f}$ ). The horizontal error bars are given by the error of the slope during loading (as shown in Figure $3 \mathrm{e}$ and $3 \mathrm{f}$ ). 
explained by the smaller coverage of $\mathrm{Mg}$-ions than $\mathrm{Ca}$-ions on the internal surface causing a lower internal repulsive electrostatic force, and hence less softening occurs when the divalent $\mathrm{Mg}^{2+}$ ions adsorb.

For chalk samples saturated with $\mathrm{Na}_{2} \mathrm{SO}_{4}$ brine, a weakening is seen when the samples have been exposed to $130^{\circ} \mathrm{C}$ either during mechanical testing or during aging before being tested at $23^{\circ} \mathrm{C}$ (Figures 4 and 5). The adsorbed divalent sulfate ions counteract the positive charge of the adsorbed $\mathrm{Ca}$-ions, but the net charge would remain positive, so the strong weakening effect could be due to the size of the sulfate ion. The Ca-ion has a diameter approximately $200 \mathrm{pm}$, whereas the sulfate ion has a diameter approximately 500 pm (Jenkins and Thankur, 1979).

Synthetic seawater contains $\mathrm{SO}_{4}{ }^{2-}$ and $\mathrm{Mg}^{2+}$, and probably due to sulfate adsorption a net softening is noticeable at high temperature and to some extent after aging. The effect is not as pronounced as in the samples with $\mathrm{Na}_{2} \mathrm{SO}_{4}$ brine, which is richer in sulfate, and as such for SSW tests, the weakening of the aged sample tested at $23^{\circ} \mathrm{C}$ is in between the $130^{\circ} \mathrm{C}$ tests and the unaged $23^{\circ} \mathrm{C}$ test. The negative sites may be covered with $\mathrm{Mg}^{2+}$ and $\mathrm{Ca}^{2+}$ (Table 3). In all, understanding how the different ions contribute to the static electric effect of the charged mineral surface relies on the concentration of


Figure 6. (a) Drained bulk modulus plotted against the porosity before the loading tests were performed. Uncertainties of the unaged cores are reported with an uncertainty of $\pm 0.05 \%$, whereas the aged cores have a certainty with $\pm 0.1 \%$. Dashed trend lines are shown with factors $K_{\text {drained }}=-0.10 \cdot \phi_{\text {init }}+5.04$, and $R^{2}=0.06$. (b) The stress at the onset of yield plotted against the porosity at yield (Table 2). An additional uncertainty of $0.05 \%$ in porosity is used. A dashed trend line is shown with $Y_{\text {ons }}=-0.74 \cdot \phi_{y}+36.1$, and $R^{2}=0.16$. Errors in the bulk modulus are the same as in Figure 3, whereas the onset of yield is reported with an estimated certainty of $\pm 0.5 \mathrm{MPa}$. the electrolyte, the size of the ion, the number of adsorption surface sites in the sample, and the distance between the adjacent calcite particles that constitute the chalk.

\section{Estimating the electrostatic component}

For a discussion of the electrostatic component of the elastic stiffness on sample scale, we propose the following modification of the Biot effective stress equation 2:

$$
\sigma^{\prime}=\sigma_{\mathrm{es}}+\sigma_{\mathrm{VdW}}=K_{\mathrm{bulk}}^{\mathrm{frame}} \varepsilon_{\mathrm{vol}} .
$$

The value of $\sigma_{\mathrm{es}}$ is given by the magnitude of the electrostatic stress, whereas $\sigma_{\mathrm{VdW}}$ represents the Van der Waals attraction. We find that $\sigma_{\mathrm{es}}$ would depend on temperature, brine composition, and mineral phases (Appendix A). This simple formulation leads us to introduce an electrostatic compressibility into Hooke's law.

A way of introducing the additive behavior of the Van der Waals and electrostatic stiffness effects is to consider the Voigt isostrain condition that applies for all triaxial experiments. The Voigt isostrain condition implies that the different stress contributions are additive, which further implies that the measured bulk modulus can
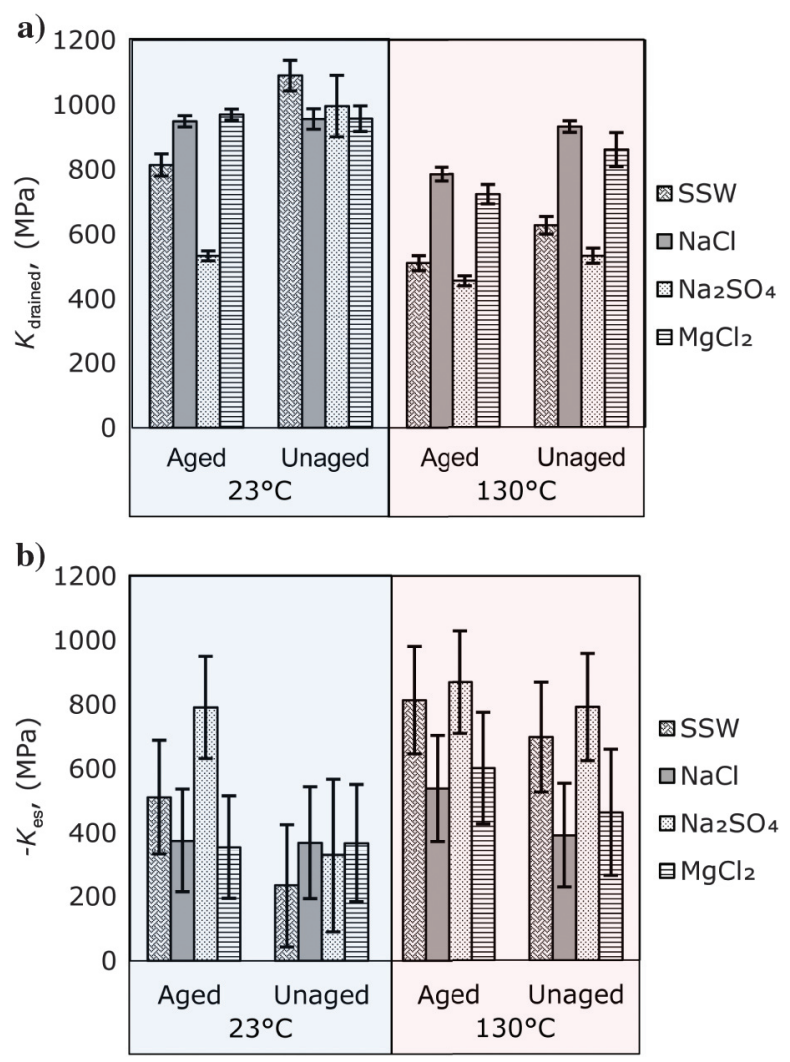

Figure 7. (a) Observed bulk modulus from the stress-strain curves at $23^{\circ} \mathrm{C}$ and $130^{\circ} \mathrm{C}$, aged and unaged, and the four brines. Error bars are the average error of the duplicated tests at equivalent conditions. (b) Electrostatic bulk modulus from the difference between the drained bulk modulus and the bulk modulus of the two oil-saturated samples (hence the negative numbers). Error bars are the sum of error in the oil-saturated samples $\left(23^{\circ} \mathrm{C}\right)$ plus the error of the water-saturated samples. 
be partitioned additively. Here, we propose using the same two components, namely, a Van der Waals component and an electrostatic component: $K_{\text {bulk }}^{\text {rame }}=K_{\mathrm{VdW}}+K_{\text {es }}$. If we know the drained bulk modulus of the same material from tests with negligible electrostatic impact ( $\sigma_{\mathrm{es}}=0$, thus $K_{\mathrm{es}}=0$ ), then, the frame bulk modulus equals the modulus from a drainage test $K_{\text {bulk }}^{\text {frame }}=K_{\mathrm{VdW}}$.

The magnitude of $K_{\mathrm{es}}$ is determined by the difference between the modulus obtained from oil-saturated tests (assumed to correspond to the stiffness of the porous rock itself) and the drained bulk modulus of the electrolyte bearing chalk via

$$
K_{\mathrm{es}}=K_{\text {drained }}-K_{\mathrm{VdW}} \cdot
$$

In Figure 7a, we show the average bulk modulus for each pair of all tests (Table 3), and the estimate of the electrostatic bulk modulus is shown in Figure 7b. The minus sign in Figure 7b arises because oil-saturated samples are stiffer than those saturated with electrolytes. The estimated uncertainty of the slope in the effective stress versus strain curve (from brine-saturated samples) increases when the uncertainty of the $K_{\mathrm{VdW}}$ (from the oil-saturated samples) is included. This leads to significantly larger uncertainty in the $K_{\text {es }}$ estimate than the measurements of $K_{\text {drained }}$. The estimated stiffness reduction, i.e., the magnitude of $K_{\text {es }}$, is larger for the $\mathrm{Na}_{2} \mathrm{SO}_{4}$ and SSW tests than the $\mathrm{MgCl}_{2}$ and $\mathrm{NaCl}$ tests, larger for $130^{\circ} \mathrm{C}$ than for $23^{\circ} \mathrm{C}$, and larger for the aged tests than the unaged tests. When combining equations 2,6 , and 7 , the electrostatic contribution to the effective stress estimate is given by

$$
\sigma_{\mathrm{es}}=K_{\mathrm{es}} \varepsilon_{\mathrm{vol}}=\left(K_{\mathrm{drained}}-K_{\mathrm{VdW}}\right) \varepsilon_{\mathrm{vol}} \text {. }
$$

The additional uncertainty in the estimates of $K_{\mathrm{es}}$ arises from the fact that the oil- and brine-saturated samples are acquired from separate Liège chalk blocks. However, the yield stress and elastic modulus in water-saturated conditions at ambient temperature are the same for the two chalk blocks. As such, we find it is justified to assume that the mechanical properties of the two blocks are similar.

The presented results may be used to improve mechanical reservoir models. This can be done by using realistic geochemical flow simulations capable of predicting the temperature, fluid pressure, ion-composition profiles, and residence time in real-reservoir systems. By incorporating the experimentally determined electrostatic bulk modulus for the different cases, the flow models may be used to estimate the extended effective stress variations throughout the reservoir in 3D space and time. In this way, water-weakening can be modeled. For example, the injection of seawater into chalk reservoirs would lead to electrostatic effects as magnesium and sulfate adsorb onto the calcite surface. The reformulated effective stress concept can therefore become useful to model deformation accurately in seawater-flooded chalk reservoirs if $K_{\mathrm{es}}$ is known from an experimental database. This would call for an even more thorough mapping of the magnitude of $K_{\mathrm{es}}$ as a function of temperature, brine composition, and residence time of the different ions present in the specific reservoir.

\section{CONCLUSION}

Previous studies have indicated how the adsorption of surfaceactive agents increases a disjoining pressure that reduces the intergranular forces at particle contacts. In addition, when time comes into play, dissolution and precipitation also alter the mechanical properties of chalk.

We found that the disjoining pressure includes an additional electrostatic stress that can be incorporated into the traditional Biot effective stress relation. At isostrain conditions, the electrostatic stress is equivalent to introducing an electrostatic stiffness modulus. The magnitude of the electrostatic modulus depends on brine composition, test temperature, and aging time. The magnitude of the extended effective stress can be estimated from the Biot coefficient and the bulk modulus of dry- or oil-saturated samples with negligible electrostatic effects.

Series of experiments were performed to map out the magnitude of the electrostatic contribution as temperature, brine composition, and residence time (i.e., aging) vary, and the results were interpreted in terms of electrostatic repulsion. We included results from 32 triaxial loading experiments with four different brines, two temperatures and aged versus unaged samples that were duplicated. In addition, stiffness and strength measurements of two oil-saturated samples were presented. Concerning bulk modulus, the magnitude of the electrostatic stress was found to depend on brine composition, temperature, and residence time, in decreasing order.

We found weakening and softening in all brine-saturated samples as compared with oil-saturated samples. Comparing the electrolyte tests, the samples containing sulfate-bearing pore water suffered the largest softening especially after aging or heating. This may be an effect of the large size of the adsorbed sulfate ions causing an expansion of the electrical double layer. By contrast, samples with magnesium-bearing brine remained relatively stiff and strong. This can be a consequence of a lower amount of adsorbed divalent cations on the internal surface when $\mathrm{Mg}^{2+}$ is the dominating ion as compared with when Ca-ions are dominating.

When temperature, brine composition, and pore pressure change through time and space, this would lead to significant changes in the extended effective stress that drive deformation. These results pave the way for incorporating geochemical flow models into mechanical models, thereby predicting water weakening of chalk in realistic scenarios.

\section{ACKNOWLEDGMENTS}

The authors acknowledge the Research Council of Norway and the industry partners; ConocoPhillips Skandinavia AS, Aker BP ASA, Eni Norge AS, Maersk Oil Norway AS, DONG Energy A/S, Denmark, Statoil Petroleum AS, ENGIE E\&P NORGE AS, Lundin Norway AS, Halliburton AS, Schlumberger Norge AS, Wintershall Norge AS, and DEA Norge AS of The National IOR Centre of Norway for support.

\section{APPENDIX A DISJOINING-PRESSURE ESTIMATE}

We estimate the disjoining pressure as a function of distance $d$ between two neighboring calcite particles using the same approach as Megawati et al. (2013, equation 12):

$$
P(d)=-A \cdot \frac{10^{27}}{6 \pi d^{3}}+\frac{1.12 \cdot 10^{6} I}{T} \psi_{0}^{2} e^{-\kappa d},
$$

where $\kappa=502.25 \sqrt{I / \varepsilon T}$. 
Table A-1. Parameters used to estimate the attractive Van der Waals forces and repulsive disjoining pressure arising from the overlap of the electrostatic potentials when surface active sulfate ions are adsorbed.

\begin{tabular}{lcc} 
Parameter & Value & Unit \\
\hline Hamaker constant $(A)$ & $5 \times 10^{-21}$ & $\mathrm{~J}$ \\
Ion strength $(I)$ & 0.25 & \\
Surface potential $\left(\psi_{0}\right)$ & -70 & $\mathrm{mV}$ \\
Dielectric constant $(\epsilon)$ & 14 & \\
Temperature & 130 & ${ }^{\circ} \mathrm{C}$ \\
Inverse Debye length $(\kappa)$ & 5.89 & $\mathrm{~nm}^{-1}$
\end{tabular}

The symbol $I$ is the ionic strength of the solution, $\psi_{0}$ is the surface potential in $\mathrm{mV}, \kappa$ is the inverse Debye length (in $\mathrm{nm}^{-1}$ ), and $\varepsilon$ is the dielectric constant of the solution corrected for temperature and brine concentration according to Revil et al. (1999). The term $A$ is the Hamaker constant, which for calcite systems can be set to $5 \times 10^{-21} \mathrm{~J}$ (Israelachvili, 1985). Note that the magnitude of the net disjoining pressure (second term) is highly sensitive to the choice of parameters. A negative disjoining pressure corresponds to attraction. The estimate of $P(d)$ is shown in Figure $2 \mathrm{~b}$, and the parameters used are displayed in Table A-1. To quantify how these disjoining pressures between two adjacent calcite surfaces add up to sample scale, several assumptions are required: First, $P(d)$ needs to be integrated from the surface outward to get the net attraction or repulsion at any given point. Then, to what extent two continuous neighboring surfaces are attracted/repelled would depend on the particle angularity and orientation (which dictates the distance between particle pairs). Then, when integrating from particle pairs to the sample scale, the interactions between all neighboring particles need to be added up, so in this paper, we refrain from attempting upscaling the forces.

\section{REFERENCES}

Ahsan, R., and I. L. Fabricius, 2010, Sorption of magnesium and sulfate ions on calcite: 72nd Annual International Conference and Exhibition, EAGE, Extended Abstracts, SP13.

Alam, M. M., R. Ahsan, A. K. Shaik, and I. L. Fabricius, 2010, Surface charge of calcite and its influence on the electrical conductivity in chalk: 80th Annual International Meeting, SEG, Expanded Abstracts, 26862691.

Andersen, P. Ø., W. Wang, M. V. Madland, U. Zimmermann, R. I. Korsnes, S. R. A. Bertolino, M. W. Minde, B. Schulz, and S. Gilbricht, 2017, Comparative study of five outcrop chalks flooded at reservoir conditions: Chemo-mechanical behavior and profiles of compositional alteration: Transport in Porous Media, 120, 1-47, doi: 10.1007/s11242-017-0953-6.

Biot, M. A., 1941, General theory of three-dimensional consolidation: Journal of Applied Physics, 12, 155-164, doi: 10.1063/1.1712886.

Croizè, D., F. Renard, K. Bjørlykke, and D. K. Dysthe, 2010, Experimental calcite dissolution under stress: Evolution of grain contact microstructure during pressure solution creep: Journal of Geophysical Research, 115, B09207, doi: 10.1029/2010JB000869.

Doornhof, D., T. G. Kristiansen, N. Nagel, P. Pattillo, and S. Sayers, 2006, Compaction and subsidence: Oilfield Review, 18, 50-68.

Fabricius, I. L., 2003, How burial diagenesis of chalk sediments controls sonic velocity and porosity: Bulletin of the American Association of Petroleum Geologists, 87, 1755-1778, doi: 10.1306/06230301113.

Fabricius, I. L., 2014, Burial stress and elastic strain of carbonate rocks: Geophysical Prospecting, 62, 1327-1336, doi: 10.1111/1365-2478.12184.

Heggheim, T., M. V. Madland, R. Risnes, and T. Austad, 2005, A chemical induced enhanced weakening of chalk by seawater: Journal of Petroleum Science and Engineering, 46, 171-184, doi: 10.1016/j.petrol.2004.12 .001 .
Hellmann, R., P. J. N. Renders, J. P. Gratier, and R. Guiguet, 2002, Experimental pressure solution compaction of chalk in aqueous solutions. Part 1: Deformation behavior and chemistry, in Water-rock interactions, ore deposits, and environmental geochemistry: A tribute to David A. Crerar: The Geochemical Society, Special Publication, 129-152.

Hermansen, H., G. H. Landa, J. E. Sylte, and L. K. Thomas, 2000, Experiences after 10 years of waterflooding the Ekofisk Field, Norway: Journal of Petroleum Science and Engineering, 26, 11-18, doi: 10.1016/ S0920-4105(00)00016-4

Hjuler, M. L., and I. L. Fabricius, 2009, Engineering properties of chalk related to diagenetic variations of Upper Cretaceous onshore and offshore chalk in the North Sea area: Journal of Petroleum Science and Engineering, 68, 151-170, doi: 10.1016/j.petrol.2009.06.005.

Huang, Y. C., F. M. Fowkes, T. B. Lloyd, and N. D. Sanders, 1991, Adsorption of calcium ions from calcite chloride solutions onto calcium carbonate particles: Langmuir, 7, 1742-1748, doi: 10.1021/la00056a028.

Israelachvili, J. N., 1985, Intermolecular and surface forces (with applications to colloidal and biological systems): Academic Press inc.

Japsen, P., A. Bruun, I. L. Fabricius, R. Rasmussen, O. V. Vejbæk, J. M. Pedersen, G. Mavko, C. Mogensen, and C. Høier, 2004, Influence of porosity and pore fluid on acoustic properties of chalk: AVO response from oil, South Arne Field, North Sea: Petroleum Geoscience, 10, 319-330, doi: 10.1144/1354-079303-586.

Jenkins, H. D. B., and K. P. Thankur, 1979, Reappraisal of thermochemical radii for complex ions: Journal of Chemical Education, 56, 576-577, doi: 10.1021/ed056p576.

Katika, K., M. Addassi, M. M. Alam, and I. L. Fabricius, 2015, The effect of divalent ions on the elasticity and pore collapse of chalk evaluated from compressional wave velocity and low-field Nuclear Magnetic Resonance (NMR): Journal of Petroleum Science and Engineering, 136, 88-99, doi: 10.1016/j.petrol.2015.10.036.

Korsnes, R. I., M. V. Madland, T. Austad, S Haver, and G. Røsland, 2008, The effects of temperature on the water weakening of chalk by seawater: Journal of Petroleum Science and Engineering, 60, 183-193, doi: 10 .1016/j.petrol.2007.06.001.

Madland, M. V., A. Hiorth, E. Omdal, M. Megawati, T. H. Hildebrand-Habel, R. I. Korsnes, S. Evje, and L. M. Cathles, 2011, Chemical alterations induced by rock-fluid interactions when injecting brines in high porosity chalks: Transport in Porous Media, 87, 679-702, doi: 10.1007/s11242-010-9708-3.

Madland, M. V., R. I. Korsnes, and R. Risnes, 2002, Temperature effects in Brazilian, uniaxial and triaxial compressive tests with high porosity chalks: SPE Annual Technical Conference and Exhibition, 77761.

Madsen, L., 2002, Surface charge of calcite, in P. Somasundaran, ed., Encyclopedia of surface and colloid science: Taylor\& Francis, 4982-4994.

Megawati, M., A. Hiorth, and M. V. Madland, 2013, The impact of surface charge on the mechanical behavior of high-porosity chalk: Rock Mechanical Engineering, 46, 1073-1090, doi: 10.1007/s00603-012-0317-z.

Megawati, M., M. V. Madland, and A. Hiorth, 2015, Mechanical and physical behavior of high-porosity chalks exposed to chemical perturbation: Journal of Petroleum Science and Engineering, 133, 313-327, doi: 10 .1016/j.petrol.2015.06.026.

Nagel, N. B., 2001, Compaction and subsidence issues within the petroleum industry: From Wilmington to Ekofisk and beyond: Physics and Chemistry of the Earth, Part A: Solid Earth and Geodesy, 26, 3-14, doi: 10 .1016/S1464-1895(01)00015-1.

Nermoen, A., R. I. Korsnes, A. Hiorth, and M. V. Madland, 2015, Porosity and permeability development in compacting chalks during flooding of nonequilibrium brines: Insights from long-term experiment: Journal of Geophysical Research: Solid Earth, 120, 2935-2960, doi: 10.1002/ 2014JB011631.

Nermoen, A., R. I. Korsnes, O. Aursjø, M. V. Madland, T. Carlsen Kjørslevik, and G. Østensen, 2016, How do stress and temperature conditions affect the rock fluid chemistry and deformation for high porosity chalk: Frontiers in Physics, 4, 1-19, doi: 10.3389/fphy.2016.00002.

Nermoen, A., R. I. Korsnes, S. Aloysius Haug, A. Hiorth, and M. V. Madland, 2014, The dynamic stability of chalks during flooding of nonequilibrium brines and $\mathrm{CO}_{2}$ : 76th Annual International Conference and Exhibition, EAGE, Extended Abstracts, C12.

Newman, G. H., 1983, The effect of water chemistry on the laboratory compression and permeability characteristics of some North Sea Chalks: Journal of Petetroleum Technology, 35, 976-980, doi: 10.2118/10203-PA.

Revil, A., 2001, Pervasive pressure solution transfer in a quartz sand: Journal of Geophysical Research, 106, 8665-8686, doi: 10.1029/2000JB900465.

Revil, A., H. Schwaeger, L. M. Cathles, and P. D. Manhardt, 1999, Streaming potential in porous media. Part 2: Theory and application to geothermal systems: Journal of Geophysical Research-Solid Earth, 104, 20033-20048, doi: 10.1029/1999JB900090.

Risnes, R., H. Haghighi, R. I. Korsnes, and O. Natvik, 2003, Chalk-fluid interactions with glycol and brines: Tectonophysics, 370, 213-226, doi: 10.1016/S0040-1951(03)00187-2

Risnes, R., M. V. Madland, M. Hole, and N. K. Kwabiah, 2005, Water weakening of chalk-Mechanical effects of water-glycol mixtures: Journal of 
Petroleum Science \& Engineering, 48, 21-36, doi: 10.1016/j.petrol.2005 .04 .004 .

Røyne, A., K. N. Dalby, and T. Hassenkam, 2015, Repulsive hydration forces between calcite surfaces and their effect on the brittle strength of calcite-bearing rocks: Geophysical Research Letters, 42, 4786-4794, doi: 10.1002/2015GL064365.

Singh Sachdeva, J., A. Nermoen, M. V. Madland, and R. I. Korsnes, 2017, Elastic and plastic behavior of chalks at deviatoric stress condition: Experiments performed with four different brines: IOR NORWAY 2017 19th Annual International Conference and Exhibition, EAGE, Extended Abstracts, Tu P030.

Stipp, S. L. S., 1999, Toward a conceptual model of the calcite surface: Hydration, hydrolysis and surface potential: Geochimica et Cosmochimica Acta, 63, 3121-3131, doi: 10.1016/S0016-7037(99)00239-2.

Sylte, J. E., L. K. Thomas, D. W. Rhett, D. D. Bruning, and N. B. Nagel, 1999, Water induced compaction and the Ekofisk field: SPE Annual Technical Conference and Exhibition, 56426. 